\title{
Research on Control Model and Simulation Platform of Cement Rotary Kiln Burning Zone Temperature
}

\author{
Hongliang $\mathrm{Yu}^{*}$, Fen Wang and Xiaohong Wang \\ School of Electrical Engineering, University of Jinan, Jinan, China \\ ${ }^{*}$ Corresponding author
}

\begin{abstract}
The research on the control model and simulation platform of rotary kiln burning zone temperature is the basis of automatic control and process optimization of cement clinker sintering process. Therefore, based on hybrid system theory, thermal regulation, and least squares method, the control model of cement rotary kiln burning zone temperature is given. Then, based on the configuration software, the dynamic simulation platform of the cement rotary kiln burning zone temperature is developed. The data and application prove the validity and practicality of the research.
\end{abstract}

Keywords-burning zone temperature; model; simulation system; cement rotary kiln

\section{INTRODUCTION}

Rotary kiln burning zone temperature is the key parameter for cement clinker sintering process. Its control method is gradually changed from the operator-based control method to the hybrid control method combined with accurate model. The research basis is the establishment of the model of the cement rotary kiln burning zone temperature and the development of the simulation platform.

Because that the burning zone temperature is too high and the cement rotary kiln rotates continuously, at present the burning zone temperature cannot be measured directly, but be gotten indirectly through colorimetric pyrometer, image processing and watching fire by operators in most of cement production lines[1]-[3]. But there are some limitations in such methods because of the presence of excessive dust and heavy smoke. The literatures [4]-[6] proposed a variety of burning zone temperature soft measurement methods. But until now there is no widely accepted research on the control model between the coal feeding and the burning zone temperature, which can meet requirements for the research on the simulation platform and control algorithm of the cement clinker sintering process.

Therefore, based on the historical data of a cement factory in Shandong Province, this paper established a number of typical working condition templates. Then based on these working conditions of the burning zone temperature the control model between the coal feeding and burning zone temperature was established. Finally, based on the configuration software, the cement rotary kiln burning zone temperature simulation platform was developed.

\section{TYPICAL WORKING CONDITION TEMPLATE OF BURNING ZONE TEMPERATURE}

Based on historical data analysis and manual experience of the operators, the working conditions are given as Table I-Table III, which covered $90 \%$ of normal running time of the production line.

Then, the soft-measurement model of the burning zone temperature under each working condition can be gotten. Such research is shown in the references [7]-[8] which were previously published by same authors. And now it will not be repeated here again.

TABLE I. WORKING CONDTION 1

\begin{tabular}{|c|c|c|c|}
\hline Serial number & Related variable & Reference value & $\begin{array}{c}\text { Allowable error } \\
\text { range }\end{array}$ \\
\hline 1 & $\begin{array}{c}\text { Raw material } \\
\text { discharge }\end{array}$ & 243.9t/h & $\pm 11.1 \mathrm{t} / \mathrm{h}$ \\
\hline 2 & $\begin{array}{l}\text { The current of } \\
\text { elevator before kiln }\end{array}$ & $135.81 \mathrm{~A}$ & \pm 2.32 \\
\hline 3 & $\begin{array}{c}\text { Decomposition } \\
\text { furnace outlet } \\
\text { temperature }\end{array}$ & $938.225^{\circ} \mathrm{C}$ & \pm 32.375 \\
\hline 4 & Kiln speed & $3.7 \mathrm{r} / \mathrm{min}$ & \pm 0.07 \\
\hline 5 & $\begin{array}{l}\text { Smoke chamber } \\
\text { temperature }\end{array}$ & $1218^{\circ} \mathrm{C}$ & $\pm 40^{\circ} \mathrm{C}$ \\
\hline 6 & Kiln motor current & $500 \mathrm{~A}$ & $\pm 60 \mathrm{~A}$ \\
\hline 7 & $\begin{array}{l}\text { Secondary air } \\
\text { temperature }\end{array}$ & $1125.69^{\circ} \mathrm{C}$ & $\pm 80^{\circ} \mathrm{C}$ \\
\hline 8 & Kiln coal feeding & $11.3 \mathrm{t} / \mathrm{h}$ & \pm 0.1 \\
\hline 9 & Cooler speed & $9.87 \mathrm{~m} / \mathrm{s}$ & \pm 1.18 \\
\hline
\end{tabular}

TABLE II. WORKING CONDTION 2

\begin{tabular}{|c|c|c|c|}
\hline Serial number & Related variable & Reference value & $\begin{array}{l}\text { Allowable } \\
\text { error range }\end{array}$ \\
\hline 1 & $\begin{array}{l}\text { Raw material } \\
\text { discharge }\end{array}$ & $246 \mathrm{t} / \mathrm{h}$ & $\pm 8 \mathrm{t} / \mathrm{h}$ \\
\hline 2 & $\begin{array}{l}\text { The current of } \\
\text { elevator before } \\
\text { kiln }\end{array}$ & $135 \mathrm{~A}$ & \pm 5 \\
\hline 3 & $\begin{array}{l}\text { Decomposition } \\
\text { furnace outlet } \\
\text { temperature }\end{array}$ & $935.8^{\circ} \mathrm{C}$ & \pm 30 \\
\hline 4 & Kiln speed & $3.725 \mathrm{r} / \mathrm{min}$ & \pm 0.095 \\
\hline 5 & $\begin{array}{l}\text { Smoke chamber } \\
\text { temperature }\end{array}$ & $1173^{\circ} \mathrm{C}$ & $\pm 233^{\circ} \mathrm{C}$ \\
\hline 6 & Kiln motor current & $454 \mathrm{~A}$ & $\pm 58 \mathrm{~A}$ \\
\hline 7 & $\begin{array}{l}\text { Secondary air } \\
\text { temperature }\end{array}$ & $1050.65^{\circ} \mathrm{C}$ & $\pm 80^{\circ} \mathrm{C}$ \\
\hline 8 & Kiln coal feeding & $11.1 \mathrm{t} / \mathrm{h}$ & \pm 0.1 \\
\hline 9 & Cooler speed & $9.52 \mathrm{~m} / \mathrm{s}$ & \pm 1.32 \\
\hline
\end{tabular}


TABLE III. WORKING CONDTION 3

\begin{tabular}{|c|c|c|c|}
\hline Serial number & Related variable & Reference value & $\begin{array}{c}\text { Allowable error } \\
\text { range }\end{array}$ \\
\hline 1 & $\begin{array}{l}\text { Raw material } \\
\text { discharge }\end{array}$ & $229.86 \mathrm{t} / \mathrm{h}$ & $\pm 13.135 \mathrm{t} / \mathrm{h}$ \\
\hline 2 & $\begin{array}{l}\text { The current of } \\
\text { elevator before kiln }\end{array}$ & $135.06 \mathrm{~A}$ & \pm 4 \\
\hline 3 & $\begin{array}{c}\text { Decomposition } \\
\text { furnace outlet } \\
\text { temperature }\end{array}$ & $911.62^{\circ} \mathrm{C}$ & \pm 27.65 \\
\hline 4 & Kiln speed & $3.8145 \mathrm{r} / \mathrm{min}$ & \pm 0.0945 \\
\hline 5 & $\begin{array}{l}\text { Smoke chamber } \\
\text { temperature }\end{array}$ & $1114.5^{\circ} \mathrm{C}$ & $\pm 117.315^{\circ} \mathrm{C}$ \\
\hline 6 & Kiln motor current & $473.2 \mathrm{~A}$ & $\pm 70 \mathrm{~A}$ \\
\hline 7 & $\begin{array}{l}\text { Secondary air } \\
\text { temperature }\end{array}$ & $1097.2^{\circ} \mathrm{C}$ & $\pm 100^{\circ} \mathrm{C}$ \\
\hline 8 & Kiln coal feeding & $10.9 \mathrm{t} / \mathrm{h}$ & \pm 0.1 \\
\hline 9 & Cooler speed & $11.27 \mathrm{~m} / \mathrm{s}$ & \pm 2.36 \\
\hline
\end{tabular}

III. RESEARCH ON CONTROL MODEL OF BURNING ZONE TEMPERATURE UNDER THE WORKING CONDITIONS

The control models of burning zone temperature under the working condition1-3 are as follows:

$y(n+1)=363.8507+1.0073 y(n)-0.3938 y(n-1)+17.163 u(n-5)-0.3$

$y(n+1)=328.7582+1.3948 y(n)-0.6885 y(n-1)-10.62 u(n-5)+18.9$ $849 u(n-6)$

$y(n+1)=147.1074+0.8356 y(n)+0.042 y(n-1)-8.9666 u(n-5)+11$. $5667 u(n-6)$

The Figure I (a), Figure I (c), Figure I (e) showed the verification input and output data under the working condition 1-3. The Figure I (b), Figure I (d), Figure I (f) showed the errors between the model outputs and the practical history data under the working condition 1-3.The error values all fluctuated within \pm 2 .

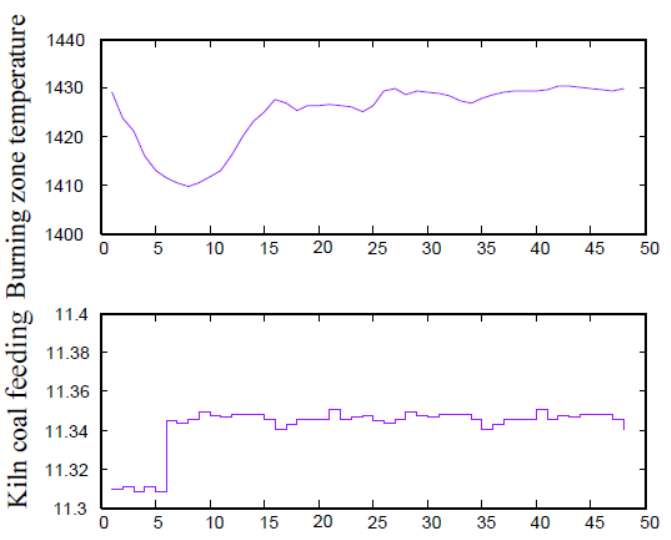

(a) Input and Output Data of Working Condition 1
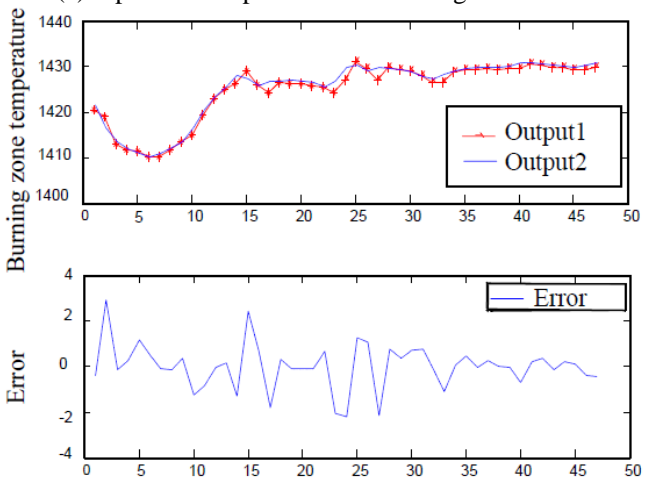

(b) Error Data of Working Condition 1
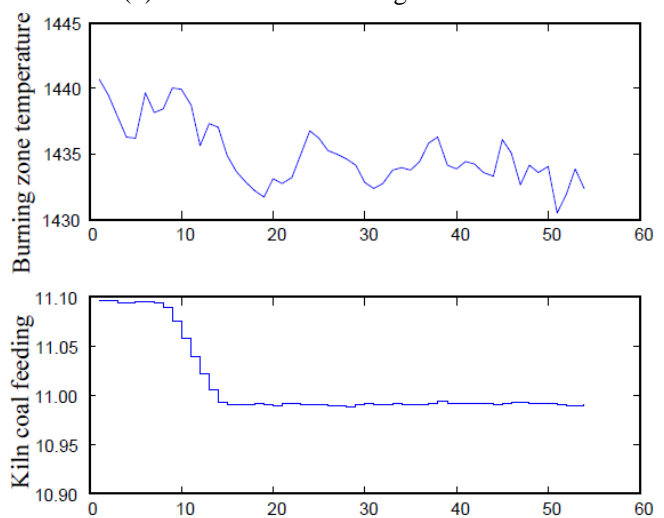

(c) Input and Output Data of Working Condition 2
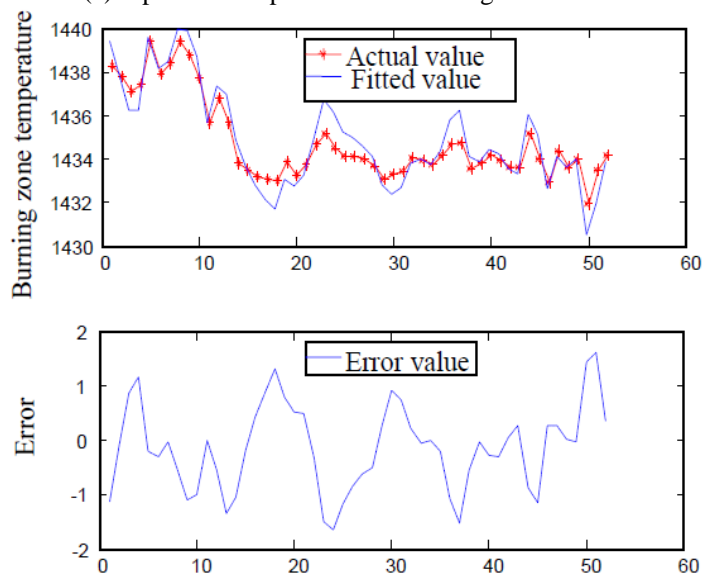

(d) Error Data of Working Condition 2 

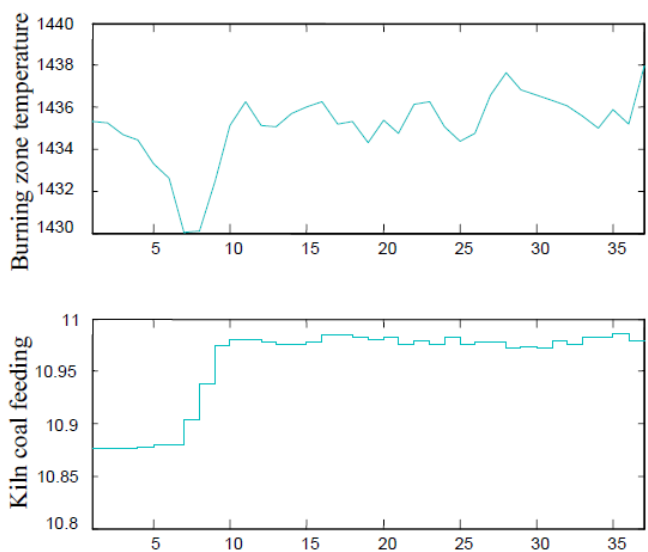

(e) Input and Output Data of Working Condition 3
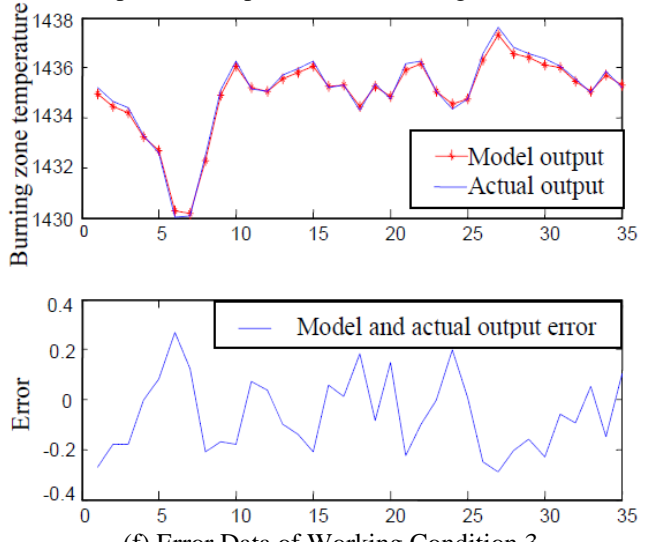

(f) Error Data of Working Condition 3

FIGURE I. COMPARISON OF DIFFERENT WORKING CONDITION

\section{REALIZATION OF THE SimUlation PlatForm OF BURNING ZONE TEMPERATURE UNDER THE WORKING CONDITIONS}

The simulation platform mainly includes the working condition recognizer, the dynamic simulation of the burning zone temperature under the working conditions, and the switching simulation of the burning zone temperature between typical working conditions. Its composition is shown in Figure II.

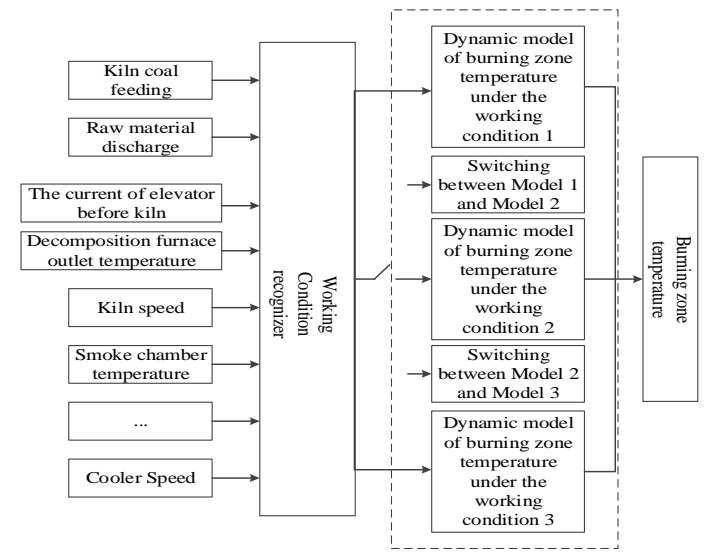

FIGURE II. COMPOSITION OF THE ROTARY KILN DYNAMIC SIMULATION PLATFORM
The simulation platform is mainly used to identify the working conditions through the relevant variables in the DCS configuration software (Freelance2013), and map the identified current operating conditions to the configuration software to select the corresponding dynamic model. The OPC channel is used as the communication method. And database is used as an intermediate data storage link, and the currently determined working condition is stored in the corresponding data table. The relevant variables are assigned via OPC to the DCS configuration software. Through the DIVIS software, the burning temperature trend is displayed on the screen. The software system architecture is shown in Figure III.

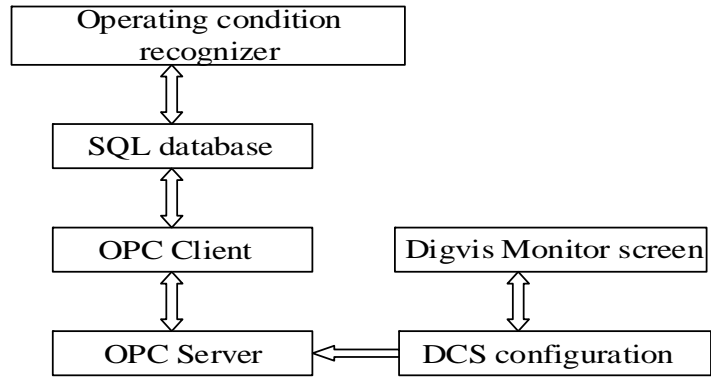

FIGURE III. SOFTWARE ARCHITECTURE OF ROTARY KILN SIMULATION PLATFORM

\section{A. Working Condition Recognizer}

The working condition recognizer can determine the current working condition, and then burning zone temperature under the correct working condition can be simulated. The working condition recognizer is established based on judging the value of each variable and the reference value of each working condition. The judging rules are as formula 4-6 to distinguish the working condition 1-3. And the variables of the recognizer rules are the same ones of the work condition templates (Raw material discharge $\mathrm{X}_{1}$, The current of elevator before kiln $\mathrm{X}_{2}$, Decomposition furnace outlet temperature $\mathrm{X}_{3}$, Kiln speed $\mathrm{X}_{4}$, Smoke chamber temperature $\mathrm{X}_{5}$, Kiln motor current $\mathrm{X}_{6}$, Secondary air temperature $\mathrm{X}_{7}$, Kiln coal feeding $\mathrm{X}_{8}$, Cooler speed $\mathrm{X}_{9}$ ).

$$
\begin{aligned}
& \left(X_{1} \rightarrow 243.9 \pm 11.1\right) \wedge\left(X_{2} \rightarrow 135.81 \pm 2.32\right) \wedge \\
& \left(X_{3} \rightarrow 938.225 \pm 32.375\right) \wedge\left(X_{4} \rightarrow 3.7 \pm 0.07\right) \wedge \\
& \left(X_{5} \rightarrow 1218 \pm 40\right) \wedge\left(X_{6} \rightarrow 500 \pm 60\right) \wedge\left(\left(X_{7} \rightarrow 1125.69 \pm 80\right)\right) \\
& \wedge\left(\left(X_{8} \rightarrow 11.3 \pm 0.1\right)\right) \wedge\left(\left(X_{9} \rightarrow 9.87 \pm 1.18\right)\right)
\end{aligned}
$$

$$
\begin{aligned}
& \left(X_{1} \rightarrow 246 \pm 8\right) \wedge\left(X_{2} \rightarrow 135 \pm 5\right) \wedge\left(X_{3} \rightarrow 935.8 \pm 3.0\right) \\
& \wedge\left(X_{4} \rightarrow 3.725 \pm 0.095\right) \wedge\left(X_{5} \rightarrow 1173 \pm 233\right) \wedge \\
& \left(X_{6} \rightarrow 454 \pm 58\right) \wedge\left(\left(X_{7} \rightarrow 1050.65 \pm 80\right)\right) \wedge \\
& \left(\left(X_{8} \rightarrow 11.1 \pm 0.1\right)\right) \wedge\left(\left(X_{9} \rightarrow 9.52 \pm 1.32\right)\right) \\
& \quad\left(X_{1} \rightarrow 229.86 \pm 13.135\right) \wedge\left(X_{2} \rightarrow 135.06 \pm 4\right) \wedge \\
& \quad\left(X_{3} \rightarrow 911.62 \pm 27.65\right) \wedge\left(X_{4} \rightarrow 3.8145 \pm 0.095\right) \wedge \\
& \quad\left(X_{5} \rightarrow 1114.5 \pm 117.315\right) \wedge\left(X_{6} \rightarrow 472.3 \pm 70\right) \wedge \\
& \quad\left(\left(X_{7} \rightarrow 1097.2 \pm 100\right)\right) \wedge\left(\left(X_{8} \rightarrow 10.9 \pm 0.1\right)\right) \wedge \\
& \quad\left(\left(X_{9} \rightarrow 11.27 \pm 2.36\right)\right)
\end{aligned}
$$


B. Dynamic Simulation of Burning Zone Temperature under Typical Working Condition

The control models of the burning zone temperature under different working conditions are established based on Freelance2013 configuration software of ABB, which mainly included hardware configuration, software programming, trend display settings, etc.

\section{Switching Simulation between Typical Working Conditions}

The switching of dynamic models is mainly happens between two typical working conditions. When the model is switched, the current dynamic model and the weight corresponding to the dynamic model to be switched are calculated. Then, the burning zone temperature simulation value is a summation value. The calculation method of model weights under typical working conditions is determined by some fuzzy rules. The specific implementation is shown in Figure IV.

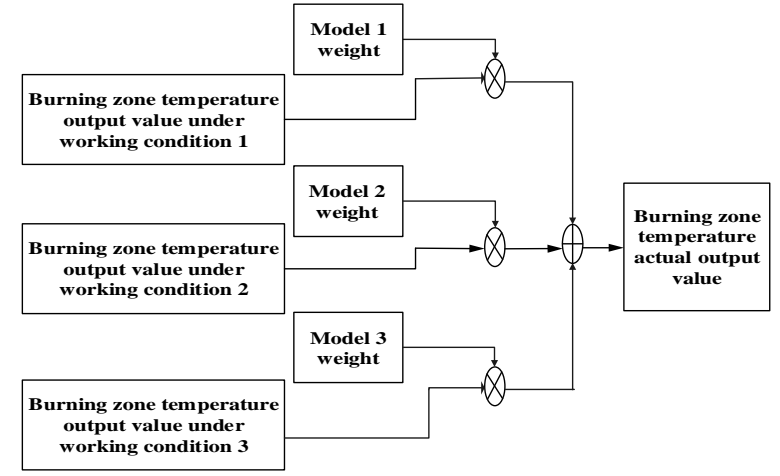

FIGURE IV. DYNAMIC MODEL SWITCHING IMPLEMENTATION

\section{CONCLUSION}

Figure $\mathrm{V}$ shows the trend of the burning zone temperature, the smoke chamber temperature, the secondary air temperature, and the decomposition furnace outlet temperature corresponding to the kiln coal feeding from $10.9 \mathrm{t} / \mathrm{h}$ to $11.1 \mathrm{t} / \mathrm{h}$ to $11.3 \mathrm{t} / \mathrm{h}$. When the Kiln coal feeding changed, the burning zone temperature also changed correspondingly. The simulation trend fitted the practical trend, which verified the validity and practicality of the research.

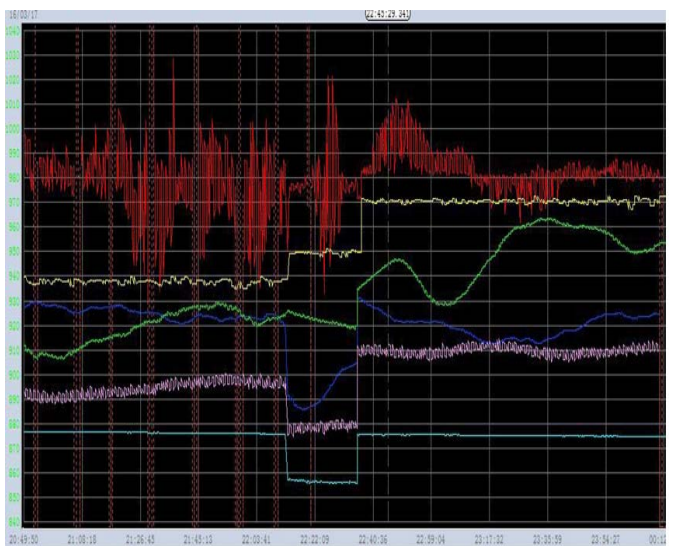

FIGURE V. HISTORY DATA CURVE OF SIMULATION PLATFORM
Note: The red curve represents the burning zone temperature, the yellow curve represents the amount of kiln coal feeding ,the blue curve represents the secondary air temperature, the green curve represents the decomposition furnace outlet temperature, the light blue curve represents the smoke chamber temperature, and the pink curve represents the Cooling machine pressure.

\section{ACKNOWLEDGEMENT}

This work was funded by the Sino-European SMEs Energy Conservation and Emission Reduction Research Cooperation Fund Project, project approval number: SQ2013ZOC600003; cement production process intelligent integration optimization control technology research and industrialization project funding, project approval number: 2014CGZH0601.

\section{REFERENCES}

[1] Yang Chunli. Research on temperature feature information extraction based on digital image of rotary kiln [D]. Harbin University of Science and Technology, 2012.

[2] Li Wei, Zhou Xiaojie, Chai Tianyou. Research on the identification method of rotary kiln firing state based on flame image[J]. Journal of Scientific Instrument, 2011, 10: 2168-2174.

[3] Lin Yanjun. Research on combustion state identification method based on flame image in rotary kiln sintering process [D]. Wuhan University of Science and Technology, 2015.

[4] Zhang Yong, Zhu Jing, Wang Leiming. Temperature prediction model of Rotary kiln firing zone Based on Improved Bp Neural Network[M]. Second International Conference on ISDEA. Sanya, China. 2012:549-552.

[5] Liu Wenguang, Wang Xiaohong, Yu Hongliang, Wu Jingjian. Study on Soft Measurement of $\mathrm{f}-\mathrm{CaO}$ in Cement Clinker Calcination Process Based on LS-SVM[J]. Control Engineering, 2008, S2: 85-88.

[6] Zhang Li, Gao Xianwen, Wang Jiesheng, Zhao Juanping. Temperature Soft Measurement of Rotary Kiln Calcination Zone Based on Model Migration Method[J]. Journal of Northeastern University(Natural Science), 2011, 02: 175-178.

[7] Wang Fen, Wang Xiaohong, Yu Hongliang. Research on dynamic modeling of firing zone of cement rotary kiln[J].Control Engineering, 2017.3, 24(3): 631-637.

[8] WANG Fen, WANG Xiao Hong, YU Hong Liang. Research on Typical Working Conditions of Calcining Zone Temperature[C]. ICADME, 2015, 10. 2158-2164. 